\title{
Two populations of glial cells from fish optic nerve/tract with distinct electrophysiological properties
}

\author{
D. Hoppe ${ }^{1 *}$, M. Bastmeyer ${ }^{2}$, G. von Blankenfeld ${ }^{1}$, H. Kettenmann ${ }^{1}$, and C.A.O. Stuermer ${ }^{2}$ \\ ${ }^{1}$ Department of Neurobiology, University of Heidelberg, Im Neuenheimer Feld 345, W-6900 Heidelberg, \\ Federal Republic of Germany \\ ${ }^{2}$ University of Konstanz, Faculty of Biology, W-7750 Konstanz, Federal Republic of Germany
}

Received May 5, 1991 / Accepted July 30, 1991

Summary. The electrophysiological properties of the two major glial cell types in cultures from the regenerating goldfish optic nerve/tract were studied with patch-clamp techniques. Spindle-shaped cells express myelin proteins. These oligodendrocyte-like cells possess outwardly rectifying currents, do not show glutamate activated currents and are rarely electrically coupled to neighboring cells. Cells of epitheloid morphology probably represent astrocytes. They are GFAP-positive and do not exhibit myelin proteins. These cells have glutamate activated currents, display a linear current to voltage relationship and are extensively electrically coupled thus displaying properties similar to mammalian astrocytes.

Key words: Goldfish - Glial cells - Ion channels - Patchclamp - Dye-coupling

\section{Introduction}

Glial cells are important companions of neurons. The glial cell environment for instance can promote or interfere with axonal growth. Central nervous system (CNS) fiber tracts in mammals fail to regenerate upon injury while severed peripheral nerves regrow successfully. Failure of axonal regeneration in the mammalian CNS is attributed to oligodendrocytes and CNS myelin which express axon-growth inhibiting molecules (Schwab 1990) as well as to reactive astrocytes which also interfere with axonal regrowth (reviewed in Franklin 1990). Schwann cells on the other hand, the glial cells of the mammalian peripheral nervous system (PNS) lack these inhibitors and promote the growth of axons (Fawcett and Keynes 1990).

In contrast to mammals some axon tracts in the CNS of fish regenerate successfully. A well known example are

\footnotetext{
* Present address: Department of Physiology, University of California, Irvine, USA

Offprint requests to: $\mathrm{H}$. Kettenmann
}

the retinal ganglion cell (RGC) axons in the fish optic nerve. Myelin of the optic nerve and other tracts of the fish CNS is not inhibitory but permissive for the growth of axons (Caroni and Schwab 1988; Bastmeyer et al. 1991). To characterize the glial cells of the fish optic nerve and to study axon/glial cell interactions, we have recently raised these cells in culture and identified oligodendrocyte-like cells and candidate astrocytes immunohistochemically (Bastmeyer et al. 1989; Bastmeyer et al. 1991). In co-culture experiments with retinal explants, the oligodendrocyte-like cells but not the candidate astrocytes proved to be growth promoting substrates for regenerating RGC axons (Bastmeyer et al. 1991). Thus, in their influence on axons the fish oligodendrocyte-like cells resemble mammalian Schwann cells rather than mammalian oligodendrocytes. To obtain further criteria for the classification of the fish optic nerve glial cells and to be able to compare them to mammalian glial cells we explored the electrophysiological characteristics and studied voltage and ligand-gated channels of these fish cells.

In mammals, astrocytes, oligodendrocytes and Schwann cells exhibit a characteristic pattern of in- and outward currents activated by de- or hyperpolarizing voltage steps (e.g. Bevan et al. 1986, 1987; Gray et al. 1986; Sontheimer and Kettenmann 1988). Moreover, astrocytes and oligodendrocytes, but not Schwann cells express glutamate receptors which show characteristics of neuronal non-NMDA receptors (Sontheimer et al. 1988; Hoppe and Kettenmann, unpublished results).

Our present results show that the electrophysiological properties of fish oligodendrocyte-like cells differ from those of mammalian oligodendrocytes, but that fish astrocytes resemble mammalian astrocytes.

\section{Material and methods}

\section{Glial cell culture}

Glial cells were obtained from the optic nerves and tracts of adult goldfish as described earlier (Bastmeyer et al. 1989). In brief, small 

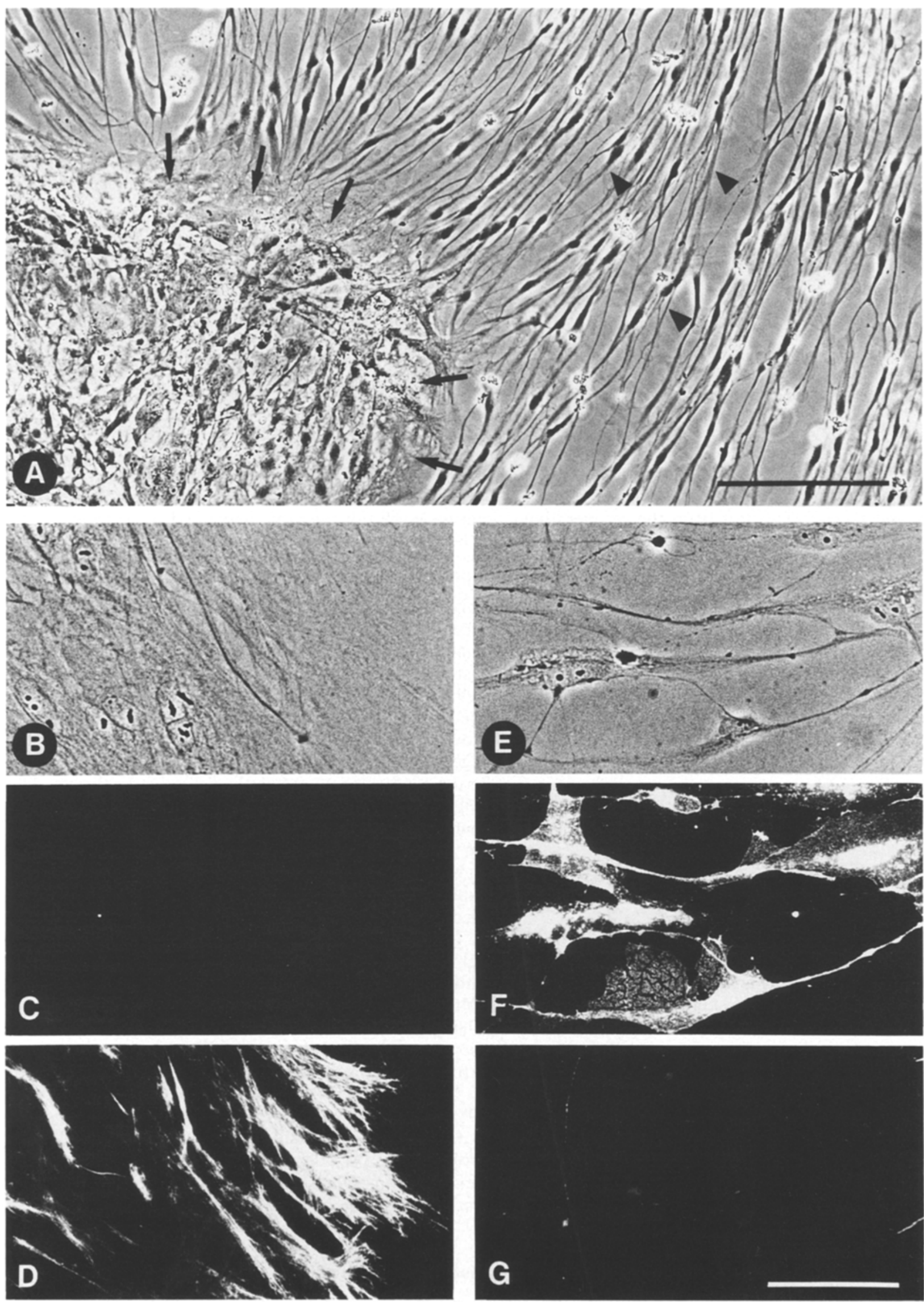

Fig. 1A-G. Morphological and immunocytochemical characterization. Phase contrast micrograph of living goldfish glial cells after 3 weeks in vitro (A). Cells of epitheloid morphology (arrows in A) and spindle-shaped cells (arrowheads in A) occupy separate territories on the coverslip. Epitheloid cells (B) are not positive for Mab 6D2

(C), specific for myelin proteins, but express the astrocytic marker GFAP (D) (B-D, identical fields). In contrast, spindle-shaped cells (E) express myelin proteins on their surface (F) and do not contain GFAP-positive fibrils (G) (E-G, identical fields). Bar in A: 200 $\mu \mathrm{m}$; Bar in $\mathbf{G}: 50 \mu \mathrm{m}$ applies to $\mathbf{B}-\mathbf{G}$ 
pieces of regenerating optic nerves and tracts (2 weeks after optic nerve section) were attached to a nylon filter (Hybond, Amersham), cut into $200 \mu \mathrm{m}$ wide segments, explanted onto polylysine/laminin coated coverslips and kept in F-12 medium (Ham's F-12 medium (Gibco), supplemented with $10 \%$ fetal calf serum and $0.4 \%$ methyl cellulose) at $28^{\circ} \mathrm{C}$. After one day in culture cells emigrate from the nerve segments and multiply.

Glial cells were identified immunocytochemically after 2-3 weeks in vitro with the monoclonal antibody (Mab) 6D2 against the fish myelin proteins IP1 and IP2 (Jeserich et al. 1990, kindly provided by $G$. Jeserich) and a polyclonal rabbit serum against fish-GFAP (Nona et al. 1989, kindly provided by S. Nona). Cells were fixed with methanol $\left(-20^{\circ} \mathrm{C}, 5 \mathrm{~min}\right)$ and formaldehyde $(2 \%$ in PBS, $5 \mathrm{~min}$ ), rinsed in PBS $(3 \times)$ and incubated simultaneously for 1 h at $37^{\circ} \mathrm{C}$ with Mab 6D2 (hybridoma supernatant diluted $1: 3$ in PBS) and anti-fish-GFAP (diluted 1: 1000 in PBS). Following three rinses in PBS the secondary antibodies (Rhodamine-coupled goat-anti-mouse and Fluorescein-isothiocyanate-coupled goatanti-rabbit antibodies, diluted $1: 200$ in PBS) were applied simultaneously for $1 \mathrm{~h}$ at $37^{\circ}$.

\section{Electrophysiological procedures}

Whole cell currents were recorded applying the patch-clamp technique (Hamill et al. 1981). Currents were amplified with an EPC-7 (List, Darmstadt, F.R.G.). Data were digitized by an interface card connected to an AT-compatible computer. A Pascal program developed in our laboratory (H.K.) was used to analyze and to display the recorded traces. The computer was also connected to the stimulus input of the patch-clamp amplifier and performed sequences of voltage steps and voltage ramps during recording.

Cells were maintained in a recording chamber on the stage of an inverted microscope at $25^{\circ} \mathrm{C}$ (Kettenmann 1988). The chamber was continuously perfused with a standard salt solution: [in $\mathrm{mM}$ ] $\mathrm{KCl} 3.0, \mathrm{NaCl} 134.0, \mathrm{CaCl}_{2} 2.2$, MOPS 10.0. The $\mathrm{pH}$ was adjusted to 7.4. Bath solutions were altered by changing the whole perfusate. Recording micropipettes were fabricated using a Narishige puller and fire-polished prior to use. The patch pipette contained [in $\mathrm{mM}$ ], $\mathrm{KCl} 117.4, \mathrm{MgCl}_{2} 2.0, \mathrm{CaCl}_{2}$ 1.0, EGTA 10.0, HEPES 10.0. The $\mathrm{pH}$ was adjusted to 7.4 .

4-AP (4-amino-pyridine) $(1 \mathrm{mM})$ and glutamate $(1 \mathrm{mM})$ were
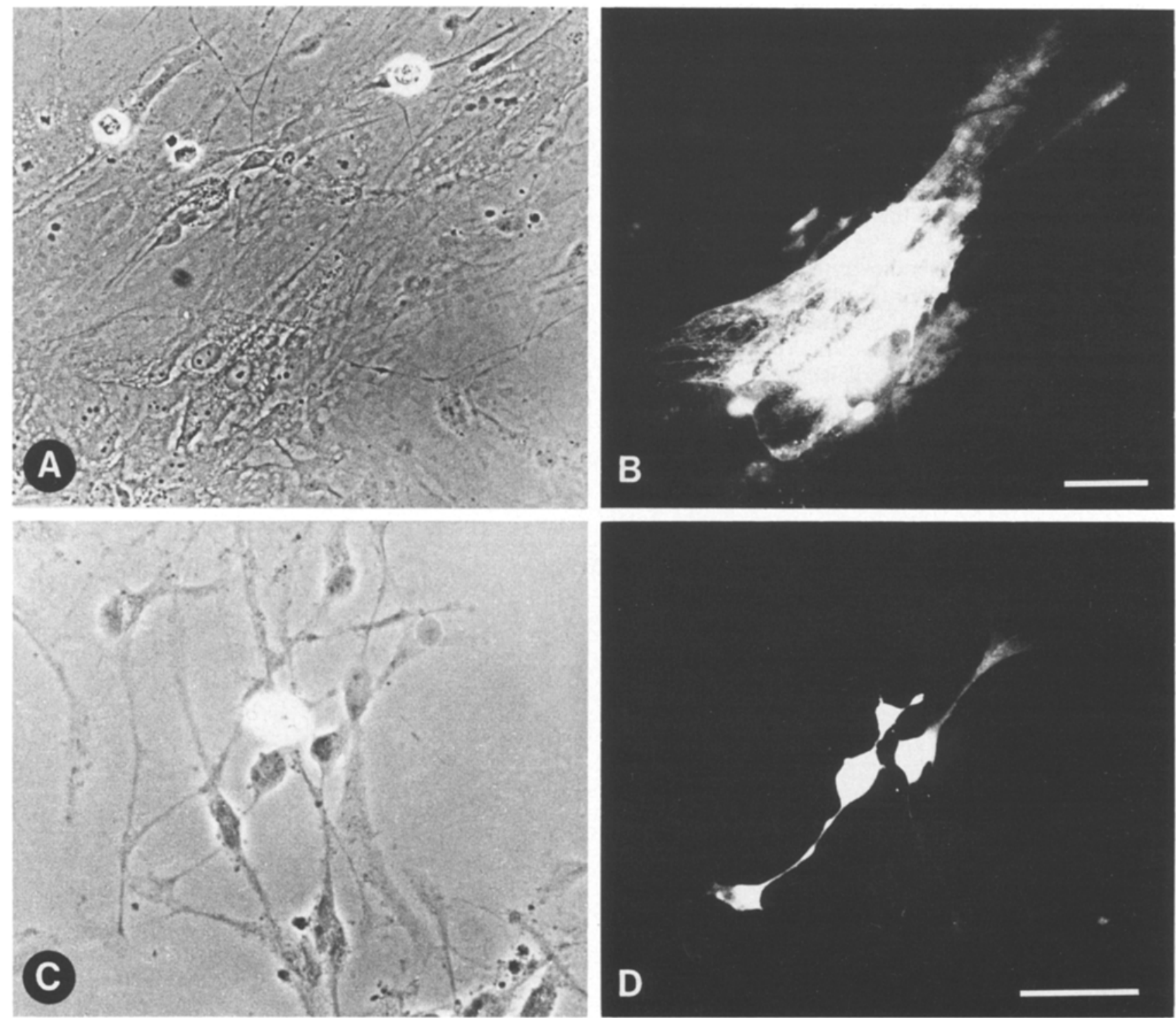

Fig. 2A-D. Lucifer Yellow injected cells. Corresponding phase contrast (A, C) and fluorescence micrographs (B, D) of Lucifer Yellow injected cells. Epitheloid cells $(\mathbf{A}, \mathbf{B})$ are coupled to a large number of surrounding cells. Spindle-shaped cells are either uncoupled or coupled to one adjacent cell $(\mathbf{C}, \mathbf{D})$. Bars in $\mathbf{B}$ and $\mathbf{D}: 50 \mu \mathrm{m}$ 
added to the standard salt solution. $\mathrm{NaCl}$ was replaced by $\mathrm{KCl}$ to increase $\left[\mathrm{K}^{+}\right]$from 3 to $50 \mathrm{mM}$. For activating currents by a change in $\mathrm{pH}_{0}$ solutions were applied via an electronically operated fast-switch multichannel superfusion system (Davies et al., 1988). This solution contained [in $\mathrm{mM}$ ], $\mathrm{NaCl} 120.0$, glucose 10.0, $\mathrm{KCl} 3.0, \mathrm{CaCl}_{2} 1.5, \mathrm{MgCl}_{2} 1.0$, buffered with $10 \mathrm{mM}$ HEPES to $\mathrm{pH}$ 7.3. The $\mathrm{pH}$ was adjusted to the desired level by adding $\mathrm{NaOH}$ or $\mathrm{HCl}$.

To test coupling between glial cells, $0.4 \%$ Lucifer Yellow was added to the electrode filling solution. After establishment of a whole cell recording, the cell was dialyzed within less than five minutes. The dye distribution was inspected at the stage of the recording microscope by using the appropriate filter set (Stewart 1981).

\section{Results}

\section{Morphological and immunocytochemical characterization of fish glial cells}

The glial cells that emigrate from small pieces of regenerating fish optic nerves and tracts multiply in vitro and occupy the entire coverslip after 1-2 weeks. Two major cell types forming separate territories are identified by morphological and immunocytochemical criteria (Fig. 1). Cells of the first type are of epitheloid morphology and form a confluent monolayer (Fig. 1 A, B). Cells of the other type are bi- or multipolar and of spindleshaped morphology. Cells of this type form a networklike array (Fig. 1A, E).

When exposed to the antibodies anti-GFAP and $\mathrm{Mab}$ 6D2 against fish myelin proteins (Jeserich et al. 1990), the epitheloid cells were found to contain GFAP-positive fibrils (Fig. 1D) and to be negative for Mab 6D2 (Fig. $1 \mathrm{C})$. The vast majority of the spindle-shaped cells $(90 \%)$ were Mab 6D2-positive which identifies them as oligodendrocyte-like cells (Fig. 1F). Only a few of these 6D2positive cells contained GFAP.

\section{Cell coupling}

Coupling between glial cells was tested by injecting the gap junction permeable dye Lucifer Yellow into individual cells via the patch-clamp pipette. We selected cells which were in physical contact to at least five neighbouring cells. The oligodendrocyte-like cells (spindle shaped cells) were coupled to one or two adjacent cells (Fig. 2C, D) or uncoupled (3 out of 6 ) such that stained cells were surrounded by unstained cells of the same type. Epitheloid cells, the candidate astrocytes, however, were always coupled to a large number of surrounding cells $(N=5)$ (Fig. 2A, B) much like cultured astrocytes from rat cortex (Kettenmann and Ransom 1988).

\section{Membrane potential and voltage activated currents}

The resting membrane potential was determined after establishment of the whole cell recording configuration. Spindle-shaped cells had a mean resting potential of $-18 \mathrm{mV}(\mathrm{SD}=8 ; N=21)$, epitheloid cells of $-56 \mathrm{mV}$ $(\mathrm{SD}=9 ; N=22)$. The membrane currents were characterized by clamping cells to a holding potential of $-70 \mathrm{mV}$ and jumping to a series of de- and hyperpolarized potentials ranging from -150 to $50 \mathrm{mV}$. The spindle-shaped cells showed either no apparent membrane currents with both de- and hyperpolarizing voltage steps or small outward currents activated by depolarizing voltage steps (Fig. 3). This outwardly rectifying behavior is also reflected in the steady state current to voltage curve obtained with voltage ramps ranging from -150 to $50 \mathrm{mV}$ ( $2 \mathrm{~s}$ duration). The epitheloid cells had in- and outward currents activated by hyper- and depolarizing voltage steps. The currents were activated rapidly with no apparent delay and slightly decayed in some cells.
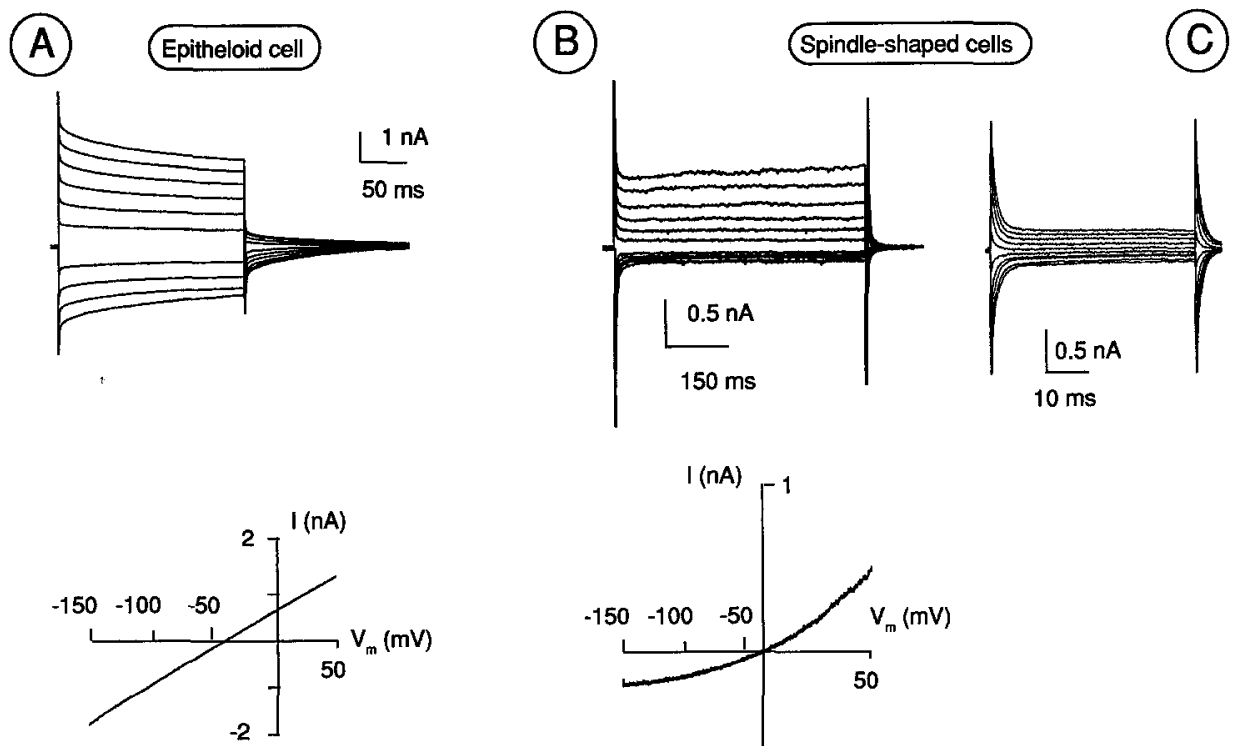

Fig. 3A-C. Membrane currents of epitheloid and spindle-shaped cells. Membrane currents were recorded with the patch-clamp technique from a epitheloid cell (A) and two different spindleshaped cells (B, C). In the upper traces, membrane currents were activated by six de- and four hyperpolarizing voltage steps from a holding potential of $-70 \mathrm{mV}$ with $20 \mathrm{mV}$ increments. Below, steady state current (I) to voltage $\left(V_{m}\right)$ curves are displayed from ramps with $2 \mathrm{~s}$ duration 

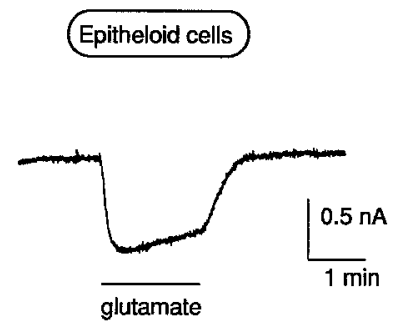

Spindle-shaped cells

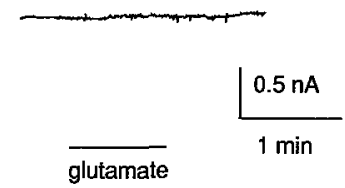

Fig. 4. Current recording during application of glutamate. During recording of membrane current from an epitheloid cell (left trace), glutamate $(1 \mathrm{mM})$ was applied as indicated by bar. The membrane potential was clamped at $-70 \mathrm{mV}$. A similar recording pattern was obtained from a spindle-shaped cell (right trace)

\section{Glutamate activated membrane currents}

Glutamate $(1 \mathrm{mM})$ was applied by bath perfusion while recording membrane currents with the membrane potential clamped at $-70 \mathrm{mV}$. In epitheloid cells, glutamate activated inward currents (Fig. $4 ; N=13$ ) with a similar time course as the glutamate-activated current in cultured astrocytes from rat cortex (Sontheimer et al. 1988 b). In the spindle-shaped cells, application of glutamate did not elicit a detectable membrane current $(N=10)$.

\section{pH-activated $\mathrm{Na}^{+}$current}

Mammalian cells of the oligodendrocyte lineage, but not mammalian astrocytes or Schwann cells exhibit $\mathrm{pH}$ activated currents (Sontheimer et al. 1989a). The presence of $\mathrm{pH}$-activated $\mathrm{Na}^{+}$currents (Konnerth et al. 1987) was tested by performing a rapid change in $\mathrm{pH}_{\mathrm{o}}$ during the recording of membrane currents according to the protocol used for mammalian glial cells (Sontheimer et al. 1989a). There was no detectable change in the resting current upon the $\mathrm{pH}$ step, either in spindleshaped cells $(N=9)$, or in epitheloid cells $(N=7)$.

\section{Discussion}

The two morphologically and immunocytochemically distinct glial cells of the goldfish optic nerve/tract exhibit cell type specific electrophysiological properties.

The GFAP-positive epitheloid fish cells were considered as candidate astrocytes. Their astrocytic nature is supported here by the finding that these cells are dyecoupled like mature mammalian astrocytes (Fischer and Kettenmann 1985). Furthermore the fish optic nerve candidate astrocytes share physiological properties with cultured astrocytes from rat and mouse cortex in exhibiting large in- and outward currents activated by de- and hyperpolarizing voltage steps and linear current to voltage-relationship (e.g. Sontheimer et al. 1988). We did not use isolation solutions to detect small $\mathrm{Na}^{+}$or $\mathrm{Ca}^{++}$ currents which are described for cultured mammalian astrocytes (Bevan et al. 1986; MacVicar 1984). After application of glutamate inward currents were elicited in the fish astrocyte-like cells with a similar time course as described for mammalian cortical astrocytes. In mammalian astrocytes the current is caused by the activation of a kainate/quisqualate type of glutamate receptor (Sontheimer et al. 1988). Thus, fish astrocyte-like cells may possess similar receptors. Like mammalian astrocytes the fish astrocyte-like cells lack $\mathrm{pH}$-activated currents. The spindle-shaped cells, the fish oligodendrocyte-like cells, express myelin proteins but differ in their electrophysiological properties from mammalian oligodendrocytes. Unlike mature mammalian oligodendrocytes and glial precursor cells they lack $\mathrm{pH}$-activated currents and glutamate responses (Gilbert et al. 1984; Sontheimer et al. 1989a). Another difference to differentiated mammalian oligodendrocytes is the earlier observation that these fish oligodendrocyte-like cells do not express the $\mathrm{Ol}$ antigen (Bastmeyer et al. 1991). Most oligodendrocyte-like cells are characterized by a marked outward rectification, which is not seen in mammalian oligodendrocytes (Soliven et al. 1988; Sontheimer and Kettenmann 1988). Such outward rectifications, however, exist in mammalian precursor cells of the oligodendrocyte lineage (Bevan et al. 1987; Sontheimer et al. 1989b) and in cultured mammalian Schwann cells (Gray et al. 1986). Fish oligodendrocyte-like cells resemble in several respects to mammalian Schwann cells. They show little current responses like myelinating Schwann cells or outward rectification like non-myelinating Schwann cells (Chiu 1988; Wilson and Chiu 1990) and lack pH- and glutamate activated currents. Furthermore they heavily proliferate in culture, another property that these cells share with mammalian Schwann cells. In mammalian Schwann cells $\mathrm{K}^{+}$channels play an important role in the control of cell proliferation. Myelinating, non proliferative cells lack somatic $\mathrm{K}^{+}$channels, while non-myelinating, proliferative cells are characterized by these channels (Chiu and Wilson 1989). Moreover, proliferation can be halted by blocking these $\mathrm{K}^{+}$channels. It is reasonable to assume that the outward rectifying properties of a subpopulation of the spindle-shaped cells are based on the expression of these delayed rectifying $\mathrm{K}^{+}$channels. They could then, like in mammalian Schwann cells also play a role in the control of proliferation in these cells.

Fish oligodendrocyte-like cells are axon growth promoting and share a large number of other properties with mammalian Schwann cells. However, these fish glial cells are isolated from the goldfish optic nerve/tract, which belongs to the CNS and has no Schwann cells. Moreover, the mode in which fish retinal axons in vivo are myelinated is clearly that of oligodendrocytes and not that of Schwann cells (Jeserich and Waehneldt 1986).

Acknowledgments. This research was supported by grants to H.K., by the Bundesministerium für Forschung und Technologie, Hermann und Lilly Schilling-Stiftung and Deutsche Forschungsgemeinschaft (Heisenberg-Stipendium, SFB 317). The authors thank S. Riese and C. Bichler for excellent technical assistance.

\section{References}

Bastmeyer M, Beckmann M, Nona SM, Cronly-Dillon JR, Stuermer CAO (1989) Identification of astrocyte- and oligoden- 
drocyte-like cells of goldfish optic nerves in culture. Neurosci Lett 101:127-132

Bastmeyer M, Beckmann M, Schwab ME, Stuermer CAO (1991) Growth of regenerating goldfish axons is inhibited by rat oligodendrocytes and CNS myelin and not by goldfish optic nerve/ tract oligodendrocyte-like cells and fish CNS myelin. J Neurosci $11: 626-641$

Bevan S, Chiu SY, Gray PTA, Ritchie JM (1986) Voltage-gated ion channels in rat cultured astrocytes. In: Ion channels in neural membranes. Alan R Liss Inc, New York, pp 159-174

Bevan S, Lindsay RM, Perkins MN, Raff MC (1987) Voltage-gated ionic channels in rat cultured astrocytes, reactive astrocytes and an astrocyte-oligodendrocyte progenitor cell. J Physiol $82: 327-335$

Caroni P, Schwab ME (1988) Two membrane protein fractions from rat central myelin with inhibitory properties for neurite growth and fibroblast spreading. J Cell Biol 106:1281-1288

Chiu, SY (1988) Changes in excitable membrane properties in Schwann cells of adult rabbit sciatic nerves following nerve transsection. J Physiol 396: 173-188

Chiu SY, Wilson GF (1989) The role of potassium channels in Schwann cell proliferation in Wallerian degeneration of explant rabbit sciatic nerves. J Physiol 408:199-222

Davies NW, Lux HD, Morad M (1989) Site and mechanism of activation of proton-induced sodium current in chick dorsal root ganglion neurones. J Physiol 400: 159-187

Fawcett JW, Keynes RJ (1990) Peripheral nerve regeneration. Ann Rev Neurosci 13:43-60

Fischer G, Kettenmann H (1985) Cultured astrocytes form a syncytium after maturation. Exp Cell Res 159:273-279

Franklin RJM, Blakemore WF (1990) The peripheral nervous system - central nervous system regeneration dichotomy: a role for glial cell transplantation. J Cell Sci 95: 185-190

Gray PTA, Bevan S, Chiu SY, Shrager P, Ritchie JM (1986) Ionic conductances in mammalian Schwann cells. In: Ion channels in neural membranes, Alan R Liss Inc, New York, pp 145-157

Hamill OP, Marty A, Neher E, Sakmann B, Sigworth FJ (1981) Improved patch-clamp techniques for high-resolution current recording from cells and cell-free membrane patches. Pflügers Arch 391:85-100

Jeserich G, Rauen T (1990) Cell cultures enriched in oligodendrocytes from the central nervous system of trout in terms of phenotypic expression exibit parallels with cultured rat Schwann cells. Glia 3:65-74

Jeserich G, Waehneldt TV (1986) Bony fish myelin: evidence for common major structural glycoproteins in central and peripheral myelin of trout. J Neurochem 46:525-533

Kettenmann H (1988) Electrophysiological methods applied in nervous system cultures. In: Boulton AA, Baker GB, and Walz W, (eds), Neuromethods Vol 10. Neurochemistry VIII. 'Brain electrolytes and water spaces' Humana Press, Clifton, pp 493-544

Kettenmann H, Ransom BR (1988) Electrical coupling between astrocytes and between oligodendrocytes in mammalian cell cultures. Glia 1:64-73

Konnerth A, Lux HD, Morad M (1987) Proton-induced transformation of calcium channel in chick dorsal root ganglion cells. J Physiol 386:603-633

MacVicar BA (1984) Voltage-dependent calcium channels in glial cells. Science 226 : 1345-1347

Nona SM, Shehab SAS, Stafford CA, Cronly-Dillon JR (1989) Glial fibrillary acidic protein (GFAP) from goldfisch: its localisation in visual pathway. Glia $2: 189-200$

Schwab ME (1990) Myelin-associated inhibitors of neurite growth and regeneration in the CNS. TINS 13:452-456

Soliven B, Szuchet S, Arnason BGW, Nelson DJ (1988) Voltagegated potassium currents in cultured ovine oligodendrocytes. J Neurosci 8:2131-2141

Sontheimer H, Kettenmann H (1988a) Heterogeneity of potassium currents in cultured oligodendrocytes. Glia 1:415-420

Sontheimer H, Kettenmann H, Backus KH, Schachner M (1988b) Glutamate opens $\mathrm{Na}^{+} / \mathrm{K}^{+}$channels in cultured astrocytes. Glia $1: 328-336$

Sontheimer H, Perouansky M, Hoppe D, Grantyn R, Lux HD, Kettenmann $\mathrm{H}$ (1989a) Expression of $\mathrm{pH}$ activated $\mathrm{Na}^{+}$channels in glia is restricted to the oligodendrocyte lineage. J Neurosci Res 24:496-500

Sontheimer H, Trotter J, Schachner M, Kettenmann H (1989b) Developmental regulation of channel expression in cultured oligodendrocytes. Neuron 2:1135-1145

Stewart WW (1981) Lucifer dyes - highly fluorescent dyes for biological tracing. Nature 292:17-21

Wilson GF, Chiu SY (1990) Potassium channel regulation in Schwann cells during early developmental myelinogenesis. J Neurosci 10:1615-1625 